АНАЛІТИЧНЕ ЗАБЕЗПЕЧЕННЯ ДІЯЛЬНОСТІ БІЗНЕСУ

\title{
УДК 657.92
}

\section{JEL Classification $\mathrm{H} 72$}

\section{Заросило Аркадій \\ старший викладач}

кафедра обліку в кредитних і бюджетних установах та економічного аналізу

ДВНЗ «Київський національний економічний університет ім. В. Гетьмана»

Київ, Україна

E-mail: z_arosylo@ukr.net

\section{МЕТОДИЧНІ ПІДХОДИ АНАЛІЗУ ДОХОДІВ І ВИТРАТ РОЗПОРЯДНИКАМИ БЮДЖЕТНИХ КОШТІВ}

\section{Анотація}

Bcmyn. Реформування бухгалтерського обліку в державному секторі обумовлюють необхідність дослідження нових методичних підходів до здійснення аналізу доходів $i$ витрат розпорядниками бюджетних коштів, формування аналітичної інформації для бюджетного прогнозування доходів і витрат з метою прийняття обгрунтованих управлінських рішень.

Методи. Інформаційною базою емпіричних досліджень слугувала створена автором база даних, що включала фінансову звітність, бюджетну звітність та кошториси 10 підприємств державного сектору за 2015-2017 роки. В якості джерела даних про стан нормативного регулювання обліково-аналітичної діяльності розпорядників бюджетних коштів в Україні слугувала база даних «Законодавство України» Верховної ради України. Методика дослідження базується на теоретичних розробках та науковому інструментарії, що включав критичний аналіз фінансової звітності, кошториси підприємств державного сектору (розпорядників бюджетних коштів) в Україні, а також аналіз нормативних документів українського законодавства.

Результати. В статті узагальнено методичні підходи аналізу доходів і витрат розпорядників бюджетних коштів. Окреслено класифікацію доходів та витрат за обмінними та необмінними операціями, визначено інформаційну базу для проведення аналізу. Запропоновано напрями та показники для аналізу доходів та витрат 3 метою їх прогнозування та оцінки ефективності використання бюджетних ресурсів.

Перспективи. В умовах рефрормування бухгалтерського обліку в державному секторі та прийняття низки нових нормативно-правових актів виникає необхідність подальшого дослідження методологічних положень аналізу доходів і витрат розпорядниками бюджетних коштів.

Ключові слова: доходи, витрати, видатки, загальний фонд, спеціальний фонд, обмінні операції, розпорядники бюджетних коштів, аналіз, прогнозування.

\section{Вступ.}

Реформування бюджетного обліку та його нормативно-законодавчої бази обумовило необхідність дослідження методичних напрямів аналізу доходів і витрат розпорядниками бюджетних коштів. Складність проведення аналізу господарської діяльності бюджетних установ полягає у відсутності єдиних підходів та специфіки господарської діяльності, оскільки бюджетні установи є неприбутковими організаціями і їх діяльність спрямована на виконання функцій держави для задоволення соціальних, культурних та інших потреб суспільства.

Оцінка ефективності використання бюджетних коштів досягається за допомогою проведення 
аналізу доходів і витрат. 3 огляду на це, застосування методичних підходів аналізу доходів і витрат розпорядниками бюджетних коштів дозволить об'єктивно оцінити ефеективність їх використання. Аналітичні розрахунки за доходами та витратами бюджетних установ здійснюють на підставі даних бухгалтерського обліку, особливо ці питання набирають більшої значущості при наближенні національної системи бухгалтерського обліку в державному секторі до міжнародних стандартів обліку та звітності для публічного сектора.

\section{Аналіз останніх джерел і публікацій.}

Дослідженню питань обліку та аналізу в державному секторі присвячено публікації низки вчених, як: П.Атамас, М.Болюх, Р. Джога, С. Левицької, О. Клименко, Т. Кондрашової, О. Кравченко, І. Кондратюк, К. Полозюк, О. Петрик, М. Сінгаєвської, С. Сушко С. Свірко, А. Фаріон, Н. Хорунжак. Незважаючи на проведені дослідження і враховуючи реформування та оновлення законодавчої та нормативної бази, дана тематика $є$ вкрай актуальною і потребує змістовного дослідження.

\section{Мета.}

Метою досліджень була розробка методичних підходів аналізу доходів, витрат і видатків загального та спеціального фондів розпорядниками бюджетних коштів.

\section{Методологія дослідження.}

У процесі дослідження застосовувались сукупність наукових методів пізнання соціальноекономічних процесів і явищ, серед яких виділено методи наукового узагальнення щодо вивчення сутності доходів і витрат за обмінними та необмінними операціями, порівняння та системного підходу до вивчення методики аналізу доходів i витрат розпорядниками бюджетних коштів. Методологічною основою дослідження слугували праці провідних вітчизняних вчених з теорії й методології економічного аналізу, нормативні та законодавчі акти з питань регулювання обліковоаналітичної діяльності розпорядників бюджетних коштів.

\section{Результати.}

Інформаційною базою для проведення аналізу діяльності бюджетних установ $є$ дані системи бухгалтерського обліку, зокрема форми фінансової звітності, бюджетної звітності та кошторис. Оновлення системи бухгалтерського обліку в державному секторі відповідно до плану заходів 3 реалізації Стратегії реформування системи управління державними фінансами на 2017-2020 роки [6], передбачає створення уніфікованої інфоормаційної системи шляхом вдосконалення системи бухгалтерського обліку та фрінансової звітності в державному секторі з урахуванням вимог міжнародних стандартів бухгалтерського обліку (IPSAS), якими передбачено перехід на єдині методичні засади бухгалтерського обліку. Співпраця України з міжнародними організаціями та фондами вимагає від розпорядників бюджетних коштів достовірну, відкриту та прозору економічну інформацію про ефективне використання бюджетних коштів.

Враховуючи оновлення нормативної бази, важливим напрямом у дослідженні $є$ визначення та класифікація доходів і витрат. Відповідно до НП(С)БОДС 101 «Подання фінансової звітності» доходами є збільшення економічних вигід у вигляді надходження активів або зменшення зобов'язань, які призводять до зростання власного капіталу; витратами є зменшення економічних вигід у вигляді вибуття активів або збільшення зобов'язань, які призводять до зменшення власного капіталу [3].

Доходи та витрати розпорядників бюджетних коштів визнаються в обліку за операціями обміну і поділяються на обмінні та необмінні операції відповідно до НП(С)БОДС 124 "Доходи" і 135 «Витрати» $[4 ; 5]$.

Обмінною операцією визначено господарську операцію з продажу або придбання активів в 
обмін на грошові кошти, послуги (роботи), інші активи або погашення зобов'язань. Відповідно необмінною операцією $€$ господарська операція, яка передбачає безоплатну передачу або отримання активів розпорядниками бюджетних коштів [4].

Класифікація доходів від обмінних та необмінних операціях наведена на рис. 1.

\begin{tabular}{|c|c|}
\hline 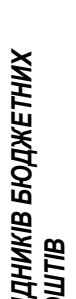 & $\begin{array}{l}\text { Доходи від обмінних операцій } \\
\text { - бюджетне асигнування; } \\
\text { - доходи від надання послуг (виконання робіт): плата за послуги, що надаються бюджетними } \\
\text { установами згідно з їх основною діяльністю; надходження бюджетних установ від додаткової } \\
\text { (господарської) діяльності; } \\
\text { - доходи від продажу (доходи від операцій з капіталом, доходи від продажу нерухомого } \\
\text { майна); } \\
\text { - доходи від відсотків, роялті та дивідендів; } \\
\text { - інші доходи від обмінних операцій }\end{array}$ \\
\hline 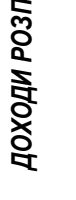 & $\begin{array}{l}\text { Доходи від необмінних операцій } \\
\text { - податкові надходження; } \\
\text { - неподаткові надходження (збори та платежі); } \\
\text { - трансфрерти та кошти, що отримують бюджетні установи від підприємств, організацій, } \\
\text { фізичних осіб та від інших бюджетних установ для виконання цільових заходів; } \\
\text { - зобов'язання, що не підлягають погашенню }\end{array}$ \\
\hline
\end{tabular}

\section{Рис. 1. Класифікація доходів від обмінних та необмінних операціях відповідно до НП(С)БОДС 124 «Доходи» [4]}

Таким чином, основними надходженнями є доходи від обмінних операцій, які включають: бюджетне асигнування; доходи від надання послуг (виконання робіт); доходи від продажу ; доходи від відсотків, роялті та дивідендів; інші доходи від обмінних операцій.

Класифікація витрат за обмінними та необмінними операціями наведена на рис. 2.

\begin{tabular}{l} 
Buтрати за обмінними операціями \\
\hline
\end{tabular}

Рис. 2. Класифікація витрат за обмінними та необмінними операціями відповідно до НП(С)БОДС 135 «Витрати» [5] 
Як видно, витрати за обмінними операціями включають: витрати на оплату праці; відрахування на соціальні заходи; матеріальні витрати, амортизація; фінансові витрати; інші витрати за обмінними операціями.

3 огляду на це, важливим напрямом роботи розпорядників бюджетних коштів $є$ проведення аналізу доходів і витрат за обмінними операціями.

Основними методами аналізу доходів і витрат $€$ вивчення їх динаміки, що дозволяє визначити абсолютні та відносні зміни кожної складової надходжень та витрачань. Визначення динаміки передує аналіз структури надходжень до бюджетного фонду. Аналіз питомої ваги надходжень та витрачань дозволяє визначити структурні зрушення, що відбулися у звітному періоді та виявити найбільш вагомі джерела фінансування. Враховуючи це, зрозуміло, що завдяки аналізу здійснюється кількісна та якісна характеристика тих змін і відхилень від планових показників, які відбуваються в установах, з'ясовуються їх причини, виявляються резерви та розробляються превентивні заходи з метою усунення виявлених негативних тенденцій на майбутнє.

Інформаційною базою для аналізу доходів і витрат за обмінними та необмінними операціями $\epsilon$ фінансова звітність, зокрема Звіт про фрінансові результати (форма № 2-дс). Відповідно до Порядку №307 структура цього звіту складається з чотирьох розділів, змістовне наповнення яких наведено в табл. 1 .

Таблиця 1

Змістовне наповнення розділів Звіту про фрінансові результати (форма № 2-дс)*

\begin{tabular}{|c|c|}
\hline № розділу & Змістовне наповнення \\
\hline Розділ I & $\begin{array}{l}\text { відображаються обсяги доходів і витрат за обмінними та необмінними операціями, за } \\
\text { результатами яких розраховується профріцит або дефріцит за звітний період. }\end{array}$ \\
\hline Розділ II & $\begin{array}{l}\text { відображаються суми видатків кошторису розпорядників бюджетних коштів в розрізі кодів } \\
\text { функціональної класифікації видатків та кредитування бюджету за звітний період та попередній } \\
\text { звітний період. }\end{array}$ \\
\hline Розділ III & $\begin{array}{l}\text { органами Казначейства та державними цільовими фондами відображається інформація про } \\
\text { виконання бюджету (кошторису) у розрізі класифікації доходів бюджету та економічної } \\
\text { класиффікації видатків і кредитування бюджету порівняно із затвердженими показниками плану на } \\
\text { звітний рік та остаточно скоригованими показниками плану на звітний період з урахуванням змін } \\
\text { (за загальним фонндом) та плану на звітний рік з урахуванням змін (за спеціальним фондом). } \\
\text { Розпорядниками бюджетних коштів не заповнюється }\end{array}$ \\
\hline Розділ IV & $\begin{array}{l}\text { наводиться інформація про елементи витрат за обмінними операціями, а саме: витрати на оплату } \\
\text { праці, відрахування на соціальні заходи, матеріальні витрати, амортизація, інші витрати }\end{array}$ \\
\hline
\end{tabular}

“Слладено за даними [7]

Таким чином, за даними звіту про фінансові результати потрібно здійснювати аналіз доходів та витрат за напрямами:

- структурно-динамічний аналіз доходів і витрат за обмінними та необмінними операціями;

- динамічний аналіз видатків кошторису розпорядників бюджетних коштів в розрізі кодів функціональної класифікації видатків та кредитування бюджету;

- структурно-динамічний аналіз елементів витрат за обмінними операціями;

- співвідношення доходів від обмінних операцій до витрат за обмінними операціями, 3 метою визначення ефективності використання бюджетних ресурсів [2, с. 67].

Зауважимо, що фінансова звітність, в тому числі звіт про фінансові результати складається щоквартально і в кінці року. 3 огляду на це, аналіз доходів та витрат потрібно здійснювати як щоквартально, так і в кінці року.

Для всебічного охоплення інформації щодо поповнення та здійснення виплат з бюджету Бюджетним кодексом України затверджено бюджетну класифікацію, яка включає класифрікацію видатків. Класифікація видатків бюджетних установ передбачає розподілення видатків на угрупування відповідно до таких класифікаційних ознак:

1) бюджетна класиффікація видатків включає: 1.1) функціональну класифікацію видатків та 
кредитування бюджету (КФКВ); відомчу класифікацію видатків та кредитування бюджету) (КВКВ); програмну класифікацію видатків та кредитування бюджету) (КПКВ); економічну класифікацію видатків бюджету (КЕКВ).

2) джерела покриття: видатки загального фонду; видатки спеціального фонду;

3) етап руху бюджетних коштів: касові видатки; фактичні видатки [1].

Інформаційною базою для аналізу доходів і видатків загального та спеціального фондів $\epsilon$ кошторис, помісячний план використання коштів спеціального фонду та зведені показники спеціального фонду кошторису. Однак ці документи мають планові показники обсягів доходів і видатків загального та спеціального фондів бюджетної установи на наступний рік.

Також, аналіз доходів і видатків загального та спеціального фондів потрібно здійснювати за даними бюджетної звітності, зокрема розпорядниками бюджетних коштів на підставі даних таких форм: Звіт про надходження та використання коштів загального фонду (форма № 2д, № 2м); Звіт про надходження і використання коштів, отриманих як плата за послуги (форма № 4-1д, № 4-1м); Звіт про надходження і використання коштів, отриманих за іншими джерелами власних надходжень (форма № 4-2 д, № 4-2м); Звіт про надходження і використання інших надходжень спеціального фонду (форма № 4-3д, № 4-3м); Звіт про надходження і використання коштів, отриманих на виконання програм соціально-економічного та культурного розвитку регіонів (форма № 4-4д); Звіт про надходження і використання інших надходжень спеціального фонду (позики міжнародних фінансових організацій) (форма № 4-3д.1, № 4-3м.1) [8].

На сьогоднішній день не створена уніфікована модель аналізу доходів і видатків загального і спеціального фондів. Систематизуючи матеріали наукових досліджень вчених, можна виділити наступні напрями аналізу доходів і видатків:

- аналіз виконання плану асигнувань загального фонду бюджету;

- аналіз виконання плану надходжень та видатків спеціального фонду бюджету;

- аналіз надходження і використання коштів загального та спеціального фонду бюджету. Аналіз руху коштів здійснюється балансовим методом на основі наступної моделі (окремо за фондами):

$$
3 \mathrm{p}_{\mathrm{n}}+\mathrm{H}=\mathrm{B}+3_{\mathrm{K}}
$$

де 3п - залишок коштів загального або спеціального фондів на початок року; Н надходження коштів за рік; В - використання коштів загального або спеціального фондів за рік; Зк залишок коштів загального або спеціального фондів на кінець року;

- факторний аналіз доходів спеціального фонду здійснюеться окремо за кожним видом надходжень на основі мультиплікативної моделі, дозволяє з'ясувати вплив окремих факторів на розмір видатків, здійснюється за використанням такої моделі:

$$
Д_{\text {сф }}=0_{\text {пा }} * B_{\text {oп }}
$$

де Дсф - доходи спеціального фонду; Опп - обсяг платних послуг ( у натуральних показниках, одиницях); Воп - вартість одиниці послуг;

- параметричний аналіз кошторису, який полягає у визначенні групи часткових та узагальнених показників, які характеризують всі важливі елементи кошторису. Аналіз проводиться за такими коефіцієнтами:

- коефіцієнт співвідношення касових видатків до фактичних;

- відношення планових надходжень до ффактичних надходжень коштів за звітний період;

- відношення видатків до доходів;

- відношення видатків спецфонду до суми власного капіталу.

Результатами аналітичних розрахунків $є$ узагальнення отриманих даних, визначення причин відхилень та розробка заходів щодо усунення негативних змін та підвищення ефективності 
використання бюджетних коштів за загальним та спеціальним фондами.

Важливим етапом при здійсненні аналізу доходів і витрат $€$ їх прогнозування як на короткостроковий період (один рік), так і на середньостроковий період (3 роки). Складання бюджету на основі середньострокових планів визначено Бюджетним кодексом України. Статтею 20 цього Кодексу передбачено складання прогнозу державного бюджету на наступні за плановим два бюджетних періоди. Базою такого прогнозу є Програма діяльності уряду, а також інші прогнозні і програмні документи соціально-економічного розвитку країни [1].

Потрібно зауважити, що планування доходів та видатків бюджету, а також фінансування бюджетних програм можливе лише за умови якісно побудованого прогнозу.

До складу індикативних прогнозних показників, необхідних для запровадження середньострокового прогнозування, входять:

- основні макропоказники соціально-економічного розвитку країни (номінальний і реальний обсяги ВВП, індекс споживчих цін, середній обмінний курс, фонд оплати праці, рівень безробіття, експорт, імпорт товарів тощо);

- показники державного та зведеного бюджетів за видами доходів, видатків і фінансування;

- показники державного боргу згідно зі стратегією управління державним боргом;

- показники державних бюджетних програм, у рамках яких здійснюється реалізація інвестиційних програм чи проектів;

- показники міжбюджетних відносин [1].

Потенційна користь від середньострокового прогнозування не підлягає сумніву, проте з ним пов'язується одна така проблема: чим довший період, на який складається прогноз, тим нижча його точність, а чим довший період, тим більше несподіваних подій неодмінно відбудеться: інфляція, регулювання чи дерегулювання, зміни тарифної політики, природні умови. Тому правильний підхід до прогнозування залежить від періоду часу, який розглядається.

Таким чином недоліками середньострокового бюджетного планування є:

- надмірне покладання на оцінки майбутніх показників при формуванні бюджету, що може призвести до негнучкості у фіскальній політиці;

- оптимістичні проектування багаторічного бюджету, які можуть бути використані як виправдання для необґрунтованих програм витрачання державних коштів;

- багаторічне бюджетування може бути складним і адміністративно затратним інструментом.

В інформаційній довідці, підготовленою Європейським інформаційно- дослідницьким центром на запит Комітету Верховної Ради України визначено, для зменшення впливу негативних факторів в середньостроковому бюджетному плануванні застосовуються основні підходи до прогнозування показників бюджетного планування, а саме:

- експертне прогнозування бюджетного планування здійснюється фахівцями, добре обізнаними із особливостями бюджетного планування, формуванням дохідної та видаткової частини;

- економічне прогнозування використовує статистичні та математичні методи, водночас його головними недоліками $€$ невисока точність результатів прогнозування і значний обсяг інформації, необхідний для його реалізації;

- прогнозування часових рядів - це прогноз бюджетних показників, який враховує їхню динаміку за минулий період часу [9].

\section{Висновки і перспективи.}

Підвищення ефрективності діяльності бюджетних установ залежить від обґрунтованості, своєчасності і достовірності отриманої інформації за даними бухгалтерської звітності з метою прийняття обгрунтованих управлінських рішень. Правильно організована робота з аналітичного дослідження діяльності бюджетних установи може забезпечити її дієвість і ефективність, обгрунтовано вплинути на загальний хід процесу діяльності сектору загального державного 
управління. Результати аналізу доходів і витрат показують обсяги розподілу коштів, визначених кошторисом, відхилення показників за останні роки, динаміку фінансування за загальним фондом і динаміку отриманих доходів по спеціальному фонду та їх використання. Аналітичні розрахунки дозволяють раціонально підійти до планування кошторису на наступний рік та розрахувати об'єктивні прогнози доходів і витрат у наступних двох бюджетних періодах. На сьогоднішній час немає чіткої методики проведення аналізу доходів і витрат бюджетних установ, обмежена кількість штатних працівників-аналітиків для більшості бюджетних установ, чим і зумовлено складність проведення аналізу та свідчить про необхідність подальшого дослідження.

\section{Список використаних джерел}

1. Бюджетний кодекс України № 2456-VI від 08.07 .2010 p. URL http://zakon0.rada.gov.ua/laws/show/2456-17 htm (дата звернення 11.09.2017).

2. Болюх М. А. Аналіз фінансово-господарської діяльності бюджетних установ. Київ : КНЕУ, 2008. 344 c.

3. Наказ Міністерства фрінансів України «Про затвердження Національного положення (стандарту) бухгалтерського обліку в державному секторі 101 «Подання фінансової звітності» № 1541від 28.12.2009 p. URL http://zakon2.rada.gov.ua/laws/show/z0103-10 htm (дата звернення 12.09.2017).

4. Наказ Міністерства фінансів України «Про затвердження Національного положення (стандарту) бухгалтерського обліку в державному секторі 124 «Доходи» № 1629 від 24.12.2010 p. URL http:// zakon0.rada.gov.ua/laws/show/z0089-11 (дата звернення 14.09.2017).

5. Наказ Міністерства фінансів України «Про затвердження Національного положення (стандарту) бухгалтерського обліку в державному секторі 135 «Витрати» № 568 від 18.05 .2012 р. URL http://zakon2.rada.gov.ua/laws/show/z0903-12 (дата звернення 11.09.2017).

6. Розпорядження Кабінета Міністрів України «Про затвердження Плану заходів з реалізації Стратегії реформування системи управління державними фінансами на 2017-2020 роки» № 415-p від 24.05.2017 p. URL http://zakon2.rada.gov.ua/laws/show/415-2017-\%D1\%80 (дата звернення 21.10.2017).

7. Наказ Міністерства фінансів України «Про затвердження Порядку заповнення форм фрінансової звітності в державному секторі» № 307 від 28.02.2017 p. URL http://zakon5.rada.gov.ua/laws/show/z0384-17 (дата звернення 22.10.2017).

8. Наказ Міністерства фінансів України «Про затвердження Порядку складання бюджетної звітності розпорядниками та одержувачами бюджетних коштів, звітності фондами загальнообов'язкового державного соціального і пенсійного страхування» № 44 від 24.01.2012 p. URL http://zakon3.rada.gov.ua/laws/show/z0196-12 (дата звернення 21.10.2017).

9. Середньострокове бюджетне планування (міжнародний досвід). Інформаційна довідка, підготовлена Європейським інформаційно-дослідницьким центром на запит Комітету Верховної Ради України. URL : http://euinfocenter.rada.gov.ua/uploads/documents/29131.pdf (дата звернення 22.10.2017).

10. Заросило А. П. Особливості аналізу доходів і витрат розпорядників бюджетних коштів. Сучасні тенденції розвитку обліку, оподаткування, аналізу і аудиту : зб. матеріалів Міжнар. наук. інтернет-конф., 17 листоп. 2017 р., м. Київ / М-во освіти і науки України, ДВНЗ «Київ. нац. екон. ун-т ім. Вадима Гетьмана», облік.екон. ф-т ; редкол.: М. І. Бондар [та ін.]. Київ : KHЕУ, 2017. С. 204-205. URL: http://ir.kneu.edu.ua/handle/2010/23416. (дата звернення 20.10.2017).

11. Погорєлов І. М., Карпович Д.М. Питання планування доходів та видатків у бюджетних установах. 12.09.2017).

URL: http://archive.nbuv.gov.ua/portal/natural/vcpi/Aprus/2012_31/ekon6.pdf (дата звернення

12. Седун Н. М., Оверчук А. В. Шляхи вдосконалення механізму формування кошторису бюджетної установи. URL : http://www.rusnauka.com

13. Хорунжак Н. М. Організація інформаційних систем і технологій обліку в бюджетних установах. Тернопіль : Вид. Стародубець, 2003. 178 с.

14. Хорунжак Н. М. Модернізація обліку і контролю в бюджетних установах в умовах системної трансформації управління: автореф. дис. на здобуття наук. ступеня д-ра екон. наук : спец. 08.00.09 бухгалтерський облік, аналіз та аудит (за видами економічної діяльності). Тернопіль : ТНЕУ, 2014. 39 с.

15. Лобода Н. Обліково-аналітичний компонент господарської діяльності установ охорони здоров'я у прагматичному контексті євроінтеграційних процесів. Інститут бухгалтерського обліку, контроль та аналіз в умовах глобалізації. 2014. Вип. 3. С. 29-31. URL: http://sophus.at.ua/publ/2014_12_16_lutsk/ 
sekcija_1_2014_12_16/oblikovo_analitichnij_komponent_gospodarskoji_dijalnosti_ustanov_okhoroni_zdorov_39_ja_ u_pragmatichnomu_konteksti_evrointegracijnikh_procesiv/74-1-0-1131 (дата звернення 02.09.2017).

16. Пігош В. Проблеми впровадження бухгалтерського обліку за НП(С)БО в державному секторі. Iнститут бухгалтерського обліку, контроль та аналіз в умовах глобалізації. 2014. Вип. 3. C. 99-102. URL: http://sophus.at.ua/publ/2014_12_16_lutsk/sekcija_2_2014_12_16/problemi_vprovadzhennja_bukhgalterskogo_obliku _za_np_s_bo_v_derzhavnomu_sektori/75-1-0-1152 (дата звернення 03.09.2017).

17. Соловйова Н. В. Облік виконання кошторисів головних розпорядників бюджетних коштів. Науковий вісник Ужгородського національного університету. 2017. Випуск 14, частина 2. С. 133-137.

18. Яковишина Н. А., Майданюк Є.В. Аналіз кошторису доходів і видатків бюджетної установи. URL: http://www.rusnauka.com/33_DWS_2013/Economics/7_150193.doc.htm (дата звернення 06.09.2017).

Статтю отримано: 16.09.2017 / Рецензування 16.10.2017 / Прийнято до друку: 14.12.2017

\author{
Arkady Zarosylo \\ Senior Instructor of Department of Accounting \\ credit and budgetary institutions and economic analysis \\ Kyiv National Economic University named after Vadym Hetman \\ Kyiv, Ukraine \\ E-mail: z_arosylo@ukr.net
}

\title{
METHODICAL APPROACHES TO ANALYSIS INCOME AND EXPENDITURE BY BUDGET FUNDS MANAGERS
}

\footnotetext{
Abstract

Introduction. The reforming of the public sector accounting requires the examination of new methodological approaches to analyzing budget administrators' incomes and expenditures; developing analytical information to forecast incomes and expenses in order to make reasonable decisions.

Methods. The author created the data basis of original financial documentation of 10 public secter enterprises in Ukraine over the period of 2015-2017 to provide the informative basis of empirical research studies. The data source on the condition of normative regulation of accounting and analytical procedures of budget fund managers in Ukraine was the data basis of legislative acts of Verkhovna Rada of Ukraine.

Research methodology is based on theoretical insights into the problem and scientific instrumentation that contained the critical content-analysis of original financial statements, reporting documents of public sector enterprise in Ukraine, comparative analysis of normative documents of Ukrainian legislative acts.

Results. The article summarizes the methodical approaches of incomes and expenditures analysis. The classification of revenues and expenses for exchange and non-exchange transactions is specified, the information base for the analysis is defined.

The directions and indicators for the analysis of income and expenses are proposed in order to forecast them and to evaluate the efficiency of using budget resources.

Discussion. In the context of the public sector accounting reformation, the further research of the methodology to analyze the incomes and expenditures by budget administrators is required

Keywords: income, expenses, expenditures, general fund, special fund, exchange operations, budget funds managers, analysis, forecasting.

\section{References}

1. Biudzhetnyi kodeks Ukrainy № 2456-VI vid 08.07.2010 r. [The Budget Code of Ukraine No. 2456-VI of July 8, 2010]. Retrivied from http://zakon0.rada.gov.ua/laws/show/2456-17 htm. [in Ukranian].

2. Boliukh, M. A. (2008). Analiz finansovo-hospodarskoi diialnosti biudzhetnykh ustanov [Analysis of financial and economic activity of budgetary institutions]. Kyiv : KNEU. [in Ukranian].

3. Nakaz Ministerstva finansiv Ukrainy «Pro zatverdzhennia Natsionalnoho polozhennia (standartu) bukhhalterskoho obliku v derzhavnomu sektori 101 «Podannia finansovoi zvitnosti» № 1541 vid 28.12.2009 r. [Order of the Ministry of Finance of Ukraine "On Approval of the National Public Accounting Standards (Public Sector Accounting Standard) 101" Presentation of Financial Statements "No. 1541] (2009). Retrivied from
} 
http://zakon2.rada.gov.ua/laws/show/z0103-10. [in Ukranian].

4. Nakaz Ministerstva finansiv Ukrainy «Pro zatverdzhennia Natsionalnoho polozhennia (standartu) bukhhalterskoho obliku v derzhavnomu sektori 124 «Dokhody» № 1629 vid 24.12.2010 r. [Order of the Ministry of Finance of Ukraine "On Approval of the National Public Sector Accounting Standards in the Public Sector 124 "Revenues" No. 1629] (December 24, 2010). Retrivied from http:// zakon0.rada.gov.ua/laws/show/z0089-11 [in Ukranian].

5. Nakaz Ministerstva finansiv Ukrainy «Pro zatverdzhennia Natsionalnoho polozhennia (standartu) bukhhalterskoho obliku v derzhavnomu sektori 135 «Vytraty» № 568 vid 18.05 .2012 r. [Order of the Ministry of Finance of Ukraine "On approval of the national (public) accounting standard in the public sector 135 "Costs "No. 568] (May 18, 2012). Retrivied from http://zakon2.rada.gov.ua/laws/show/z0903-12 [in Ukranian].

6. Rozporiadzhennia Kabineta Ministriv Ukrainy «Pro zatverdzhennia Planu zakhodiv z realizatsii Stratehii reformuvannia systemy upravlinnia derzhavnymy finansamy na 2017-2020 roky» № 415-r vid 24.05.2017 r. [Cabinet of Ministers of Ukraine Order "On Approval of the Action Plan for Implementation of the Strategy for Reforming the Public Finance Management System for 2017-2020" No. 415-r] (May 24, 2017). Retrivied from http://zakon2.rada.gov.ua/laws/show/415-2017-\%D1\%80 [in Ukranian].

7. Nakaz Ministerstva finansiv Ukrainy «Pro zatverdzhennia Poriadku zapovnennia form finansovoi zvitnosti v derzhavnomu sektori» № 307 vid 28.02.2017 r. [Ministry of Finance of Ukraine Order "On Approval of the Procedure for Filing Public Financial Reporting Forms in the Public Sector" No. 307] (February 28, 2017). Retrivied from http://zakon5.rada.gov.ua/laws/show/z0384-17 [in Ukranian].

8. Nakaz Ministerstva finansiv Ukrainy «Pro zatverdzhennia Poriadku skladannia biudzhetnoi zvitnosti rozporiadnykamy ta oderzhuvachamy biudzhetnykh koshtiv, zvitnosti fondamy zahalnooboviazkovoho derzhavnoho sotsialnoho i pensiinoho strakhuvannia» № 44 vid 24.01.2012 r. [Ministry of Finance of Ukraine Order "On Approval of the Procedure for Preparing Budget Reporting by Managers and Recipients of Budget Funds, Reporting by Mandatory State Social and Pension Insurance Funds" No. 44] (January 24, 2012). Retrivied from http://zakon3.rada.gov.ua/laws/show/z0196-12 [in Ukranian].

9. Serednostrokove biudzhetne planuvannia (mizhnarodnyi dosvid). Informatsiina dovidka, pidhotovlena Yevropeiskym informatsiino-doslidnytskym tsentrom na zapyt Komitetu Verkhovnoi Rady Ukrainy [Medium-term budget planning (international experience). Information note prepared by the European Information and Research Center at the request of the Verkhovna Rada Committee of Ukraine]. Retrivied from http://euinfocenter.rada.gov.ua/uploads/documents/29131.pdf [in Ukranian].

10. Zarosylo, A. P. (November 17, 2017). Osoblyvosti analizu dokhodiv i vytrat rozporiadnykiv biudzhetnykh koshtiv. Suchasni tendentsii rozvytku obliku, opodatkuvannia, analizu i audytu : zb. materialiv Mizhnar. nauk. internetkonf., 17 lystop. 2017 r., m. Kyiv [Characteristics of the analysis of incomes and expenditures of managers of budgetary funds. Papers presented at the Intern. sciences. Internet-Conf. of KNEU]. KNEU, Kyiv. Retrivied from http://ir.kneu.edu.ua/handle/2010/23416. [in Ukranian].

11. Pohorielov, I. M., \& Karpovych, D.M. Pytannia planuvannia dokhodiv ta vydatkiv u biudzhetnykh ustanovakh [Planning of incomes and expenses in budgetary institutions]. Retrivied http://archive.nbuv.gov.ua/portal/natural/vcpi/Aprus/2012_31/ekon6.pdf [in Ukranian].

12. Sedun, N. M., \& Overchuk, A. V. Shliakhy vdoskonalennia mekhanizmu formuvannia koshtorysu biudzhetnoi ustanovy [Issues of income and expenditure planning in budgetary institution]. Retrivied from http://www.rusnauka.com [in Ukranian].

13. Khorunzhak, N. M. (2003). Orhanizatsiia informatsiinykh system i tekhnolohii obliku v biudzhetnykh ustanovakh [Organization of information systems and accounting technologies in budget institutions]. Ternopil : Vyd. Starodubets. [in Ukranian].

14. Khorunzhak, N. M. (2014). Modernizatsiia obliku i kontroliu v biudzhetnykh ustanovakh $v$ umovakh systemnoi transformatsii upravlinnia: avtoref. dys. na zdobuttia nauk. stupenia d-ra ekon. nauk [Modernization of accounting and control in budget institutions in the context of systemic management transformation (Author's abstract dissertation)]. TNEU, Ternopil. [in Ukranian].

15. Loboda, N. (2014). Oblikovo-analitychnyi komponent hospodarskoi diialnosti ustanov okhorony zdorovia u prahmatychnomu konteksti yevrointehratsiinykh protsesiv [The accounting and analytical component of the economic activities of health care institutions in the pragmatic context of European integration processes]. Instytut bukhhalterskoho obliku, kontrol ta analiz v umovakh hlobalizatsii, 3, 29-31. [in Ukranian].

16. Pihosh, V. (2014). Problemy vprovadzhennia bukhhalterskoho obliku za NP(S)BO v derzhavnomu sektori [Problems of introduction of accounting for NP(C)BU in the public sector]. Instytut bukhhalterskoho obliku, kontrol ta analiz $v$ umovakh hlobalizatsii, 3, 99-102. Retrivied from http://sophus.at.ua/publ/2014_12_16_lutsk/ 
sekcija_2_2014_12_16/problemi_vprovadzhennja_bukhgalterskogo_obliku_za_np_s_bo_v_derzhavnomu_sektori/751-0-1152 [in Ukranian].

17. Soloviova, N. V. (2017). Oblik vykonannia koshtorysiv holovnykh rozporiadnykiv biudzhetnykh koshtiv [Accounting expenses of budget funds main owners]. Naukovyi visnyk Uzhhorodskoho natsionalnoho universytetu, 14, part 2, 133-137.

18. Yakovyshyna, N. A., \& Maidaniuk, Ye.V. Analiz koshtorysu dokhodiv i vydatkiv biudzhetnoi ustanovy [Analysis of the budget estimates of income and expenditure of a budgetary institution]. Retrivied from http://www.rusnauka.com/33_DWS_2013/Economics/7_150193.doc.htm [in Ukranian].

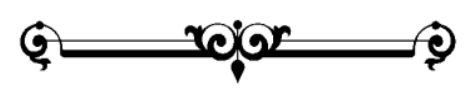

